\title{
Effect of Lactobacillus plantarum Fermentation on the Surface and Functional Properties of Pea Protein-Enriched Flour
}

\section{Burcu Çabuk, Andrea K. Stone, Darren R. Korber, Takuji Tanaka and Michael T. Nickerson*}

Department of Food and Bioproduct Sciences, University of Saskatchewan, 51 Campus Drive, Saskatoon, SK, S7N $5 \mathrm{~A} 8$, Canada

Received: 30 July 2017 Accepted: 13 July 2018

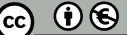

*Corresponding author:

Phone: +13069665030 ;

Fax: +13069668898;

E-mail: Michael.Nickerson@usask.ca

ORCID IDs: 0000-0001-8836-6047

(Çabuk), 0000-0002-0918-1966 (Stone), 0000-0001-6350-209X (Korber) 0000-0003-3304-5830 (Tanaka), 0000-0002-9040-5639 (Nickerson)

\section{SUMMARY}

The effect of Lactobacillus plantarum fermentation on the functional and physicochemical properties of pea protein-enriched flour (PPF) was investigated. Over the course of the fermentation the extent of hydrolysis increased continuously until reaching a maximum degree of hydrolysis of $13.5 \%$ after $11 \mathrm{~h}$. The resulting fermented flour was then adjusted to either $\mathrm{pH}=4$ or 7 prior to measuring the surface and functional attributes as a function of fermentation time. At $\mathrm{pH}=4$ surface charge, as measured by zeta potential, initially increased from +14 to $+27 \mathrm{mV}$ after $1 \mathrm{~h}$ of fermentation, and then decreased to $+10 \mathrm{mV}$ after $11 \mathrm{~h}$; whereas at $\mathrm{pH}=7$ the charge gradually increased from -37 to $-27 \mathrm{mV}$ over the entire fermentation time. Surface hydrophobicity significantly increased at $\mathrm{pH}=4$ as a function of fermentation time, whereas at $\mathrm{pH}=7$ fermentation induced only a slight decrease in PPF surface hydrophobicity. Foam capacity was highest at $\mathrm{pH}=4$ using PPF fermented for $5 \mathrm{~h}$ whereas foam stability was low at both $\mathrm{pH}$ values for all samples. Emulsifying activity sharply decreased after $5 \mathrm{~h}$ of fermentation at $\mathrm{pH}=4$. Emulsion stability improved at $\mathrm{pH}=7$ after $5 \mathrm{~h}$ of fermentation as compared to the control. Oil-holding capacity improved from $1.8 \mathrm{~g} / \mathrm{g}$ at time 0 to $3.5 \mathrm{~g} / \mathrm{g}$ by the end of $11 \mathrm{~h}$ of fermentation, whereas water hydration capacity decreased after $5 \mathrm{~h}$, then increased after $9 \mathrm{~h}$ of fermentation. These results indicate that the fermentation of PPF can modify its properties, which can lead towards its utilization as a functional food ingredient.

Key words: pea protein-enriched flour, fermentation, functional properties, lactic acid bacteria

\section{INTRODUCTION}

Dry edible pea (Pisum sativum) is widely consumed around the globe as a healthy food. Peas are rich in proteins, carbohydrates, fibre, and vitamins/minerals, and are low in fat (1). The protein content of pea is higher than many other staple foods, thus pea is considered a good protein source. Pea protein is rich in lysine, but deficient in the thiol-containing amino acids (cysteine and methionine) (2,3). As such, it is commonly recommended that one consume pulses such as pea along with cereal grains in order to obtain a complete essential amino acid profile (4), especially in places where animal protein is limited and expensive due to issues of food insecurity. While peas are a good protein source, they also contain secondary metabolites considered to be anti-nutritional factors, such as enzyme inhibitors (trypsin and chymotrypsin inhibitors), oxalates, phytates, oligosaccharides, phenolics, tannins and lectins, that inhibit protein digestion or mineral absorption when consumed (5).

Peas are usually eaten whole or split, milled into flour (21-24\% protein), air classified into either a protein-enriched flour (30-50 \% protein) or a protein concentrate (50-80 \% protein), or wet processed into a protein isolate ( $>80 \%$ protein) (6). Each particular fraction may be incorporated into different products, applications or sectors. Animal-derived proteins from milk (casein, whey) and egg (ovalbumin), along with plant sources such as wheat (gluten) and soy (glycinin, conglycinin) dominate the protein ingredient market (7). However, consumers are demanding an increase in alternative protein sources due to the allergen content of the current protein products. Accordingly, a rise in the demand for pea protein products 
has occurred since they tend to have low allergenicity. In addition, pea protein products have other market benefits, including not being genetically modified, low in cost, nutritious and functional $(8,9)$. As the demand for pea increases, so too does the need for greater variations and choice in pea protein ingredients; processing, such as infrared heating, germination, enzymatic modification and fermentation can alter the ingredients (9). Fermentation is of great interest to industry as it is a non-thermal process whose technology acts to partially unravel the protein conformation to expose buried reactive amino acids and improve its digestibility (10). The use of bacteria or fungi to produce proteases is essential to fermentation processes, as they not only initiate partial protein unfolding but also facilitate the release of low-molecular-mass peptides with potential bioactive properties (11-13). Fermentation also acts to reduce the content of anti-nutritional factors within pulse ingredients, and help improve mineral absorption through the production of organic acids which form soluble complexes with minerals, rendering the minerals unavailable to react with phytates and become insoluble (14-16).

Fermented pulses are consumed primarily in Asia, Africa and Europe, with less uptake in North America. However, limited research efforts have been reported on the effects of fermentation conditions on the functional properties of commercial pea protein ingredients, such as a protein-enriched flour. The overall goal of the present study is to examine the impact of fermentation of pea protein-enriched flour by Lactobacillus plantarum on the protein surface and functional properties at $\mathrm{pH}=4$ (indicative of an acidic food, and near pea protein isoelectric point; $\mathrm{pl}$ ) and $\mathrm{pH}=7$ (indicative of the neutralization process in wet processing, and away from pea protein $\mathrm{pl}$ ) in order to diversify the pea ingredient line for greater market integration. Fermentation studies commonly use L. plantarum due to its generally recognized as safe (GRAS) status, growth ability and its ubiquitous nature in fermented food products (17). We chose it for this study because of its growth requirements, i.e. the required fermentation conditions do not affect the pea protein quality.

\section{MATERIALS AND METHODS}

\section{Materials}

Parrheim Foods (Saskatoon, SK, Canada) kindly donated the air-classified pea protein-enriched flour (PPF). 8-Anilino-1-naphthalenesulfonic acid (ANS) and 5,5'-dithiobis-2-nitrobenzoic acid (DNTB) were products of Sigma-Aldrich (Oakville, ON, Canada), MRS broth was a product of Oxoid (Nepean, ON, Canada), whereas all other chemicals used were of reagent grade and purchased through Fisher Scientific (Ottawa, ON, Canada). A Millipore Milli- $Q^{T M}$ water purification system (Millipore Corp., Etobicoke, ON, Canada) produced the water used in this stidy. Canola oil (Great Value ${ }^{\mathrm{TM}}$, Wal-Mart Canada Corp., Mississauga, ON, Canada) was purchased from a local supermarket. Lactobacillus plantarum NRRL B-4496 was obtained from the Agricultural Research Service Culture Collection, USDA (Peoria, IL, USA).

\section{Fermentation}

A growth curve for Lactobacillus plantarum NRRL B-4496 was initially prepared within MRS broth (Oxoid) for approx. $24 \mathrm{~h}$ at $32{ }^{\circ} \mathrm{C}$ under anaerobic conditions. For fermentation experiments cell cultivation lasted until the late exponential phase of growth (approx. $10 \mathrm{~h}$ ), followed by centrifugation (10 000 $\times g, 20 \mathrm{~min}, 4^{\circ} \mathrm{C}$; centrifuge model 5810R; Eppendorf, Mississauga, ON, Canada), and then washing twice with peptone solution. The resulting pellet was used as the inoculum for fermentation. Lactobacillus plantarum was added to a $25 \%$ $(\mathrm{m} / \mathrm{V})$ PPF solution $(400 \mathrm{~mL})$ in an Erlenmeyer flask at a content of 7 log CFU per $g$ PPF, which was then incubated under anaerobic conditions at $32^{\circ} \mathrm{C}$ for $11 \mathrm{~h}$. Enumeration of L. plantarum was carried out by plating onto MRS medium (Oxoid) at $37^{\circ} \mathrm{C}$ for $48 \mathrm{~h}$ under anaerobic conditions. Anaerobic conditions were maintained by placing the experiments within a rectangular jar with Anaerogen anaerobic gas generating kit (Thermo Scientific, Waltham, MA, USA). Aliquots $(60 \mathrm{~mL})$ were taken at $0,1,5,9$ and $11 \mathrm{~h}$ of fermentation and then freezedried for $48 \mathrm{~h}$ using a freeze dryer (Labconco, Freezone 12, Kansas City, MO, USA). All dried samples were then ground using a coffee grinder (model 80365; Hamilton Beach Custom Grind $^{\mathrm{TM}}$, Glen Allen, VA, USA). Fermentation experiments were run in triplicate, yielding three separate fermented PPF for each time point.

\section{Composition}

Moisture content was determined gravimetrically by calculating the mass loss after drying $2 \mathrm{~g}$ sample in an oven (APT.line ${ }^{\mathrm{TM}} \mathrm{ED}$, BINDER GmbH, Tuttlingen, Germany) at $130^{\circ} \mathrm{C}$ for $1 \mathrm{~h}$, according to AOAC method 925.10 (18). Protein content $(\mathrm{N} / \% \cdot 6.25)$ was determined according to AOAC method 920.87 (19) using a Kjeldahl micro digestor (model 6030000; Labconco) and distillation unit (Rapid Still I; Labconco). Ash content was determined according to AOAC method 923.03 (20) in which $3 \mathrm{~g}$ sample was placed overnight in a muffle furnace (Isotemp ${ }^{\circledR}$; Thermo Fisher Scientific, Waltham, MA, USA) at $550^{\circ} \mathrm{C}$ and expressed as the difference of the mass of the sample before and after heating. Crude lipid was determined gravimetrically after solvent extraction with ether according to AOAC method 920.39 (21) using a Labconco Goldfisch fat extractor. Proximate analysis was reported on a dry mass basis. To determine the $\mathrm{pH}, 15 \mathrm{~g}$ of PPF fermentation medium at each time interval $(0,1,5,9$, and $11 \mathrm{~h})$ were transferred to a 25- $\mathrm{mL}$ beaker and the $\mathrm{pH}$ was measured under stirring conditions using a pH meter (B10P Benchtop Meter; VWR, Mississauga, ON, Canada) and magnetic stirrer plate (RO 5; IKA Works Inc., Wilmington, NC, USA).

\section{Degree of hydrolysis}

The degree of hydrolysis (DH/\%) of fermented PPF samples was calculated according to Adler-Nissen (22) using the following formulae: 


$$
Y_{\mathrm{h}}=\left(c_{\mathrm{t}}-c_{\mathrm{c}}\right) \cdot \mathrm{DF}
$$

and

$$
\mathrm{DH}=\frac{\mathrm{C}}{c_{\text {tot }}} \cdot 100
$$

where $Y_{h}$ is the yield of hydrolysis equivalents (of a-amino groups formed during the hydrolysis reaction; or a- $\mathrm{NH}_{2}-\mathrm{Gly}$ equivalent), $c_{t}$ is the millimolar concentration of $\mathrm{a}-\mathrm{NH}_{2}-\mathrm{Gly}$ equivalent (measured using a glycine standard curve) obtained from the trypsin-catalyzed protein hydrolysis reactions, $c_{c}$ is the millimolar concentration of a- $\mathrm{NH}_{2}$-Gly equivalent from the non-trypsin treated PPF (control), $c_{\text {tot }}$ is the millimolar concentration of $\mathrm{a}-\mathrm{NH}_{2}$-Gly equivalent from the total PPF hydrolysis, and DF is a dilution factor.

\section{Surface properties}

\section{Surface charge}

The surface charge (or zeta potential) of each fermented sample was determined according to Can Karaca et al. (23). In brief, $0.05 \%$ (by mass) of protein was dissolved in Milli-Q water (Millipore Corp.) and adjusted to $\mathrm{pH}=4.0$ or 7.0 with $0.5 \mathrm{M}$ $\mathrm{NaOH}$ or $\mathrm{HCl}$. The solution was then stirred overnight at 500 rpm using a magnetic stirrer plate (RO 5; IKA Works Inc.) at room temperature $\left(21-23^{\circ} \mathrm{C}\right)$. The electrophoretic mobility was measured using a Zetasizer Nano (Malvern Instruments, Westborough, MA, USA). The zeta-potential ( $/ / \mathrm{mV}$ ) was determined from the electrophoretic mobility $\left(\mu_{\mathrm{E}}\right)$ using Henry's equation, as follows:

$$
\mu_{\mathrm{E}}=2 \varepsilon \cdot \zeta \cdot f(\kappa \alpha) / 3 \eta
$$

where $\eta$ is the dispersion viscosity, $\varepsilon$ is the permittivity, and $f(\kappa a)$ is a function related to the ratio of particle radius $(a)$ and the Debye length $(\kappa)$.

\section{Surface hydrophobicity}

Surface hydrophobicity of fermented samples was determined with 8-anilino-1-naphthalenesulfonic acid (ANS) fluorescent probe (Sigma-Aldrich) using the modified method of Kato and Nakai (24). Briefly, a $0.025 \%$ (by mass) protein solution was prepared in Milli-Q water (Millipore Corp.), adjusted to $\mathrm{pH}=4$ or 7.0 using $0.5 \mathrm{M} \mathrm{NaOH}$ or $\mathrm{HCl}$, and stirred overnight at 500 rpm using a magnetic stirrer (RO 5; IKA Works Inc.) at room temperature. The stock solution was then diluted to final protein mass fractions of $0.005,0.010,0.015$, and $0.020 \%$. A $20-\mu \mathrm{L}$ aliquot of $8 \mathrm{mM}$ ANS solution (in Milli- $\mathrm{Q}$ water, $\mathrm{pH}=4$ or 7) was added to $1.6 \mathrm{~mL}$ of each protein mass fraction, vortexed for $10 \mathrm{~s}$ and kept in the dark for $5 \mathrm{~min}$. The fluorescence intensity was measured with a FluoroMax-4 spectrofluorometer (Horiba Jobin Yvon Inc., Edison, NJ, USA) using excitation and emission wavelengths of 390 and $470 \mathrm{~nm}$, respectively, and a slit width of $1 \mathrm{~nm}$. Sample blanks were prepared by adding
$20 \mu \mathrm{L}$ of Milli-Q water ( $\mathrm{pH}=4$ or 7 ) to the protein solutions instead of the ANS probe (Sigma-Aldrich). The initial slope of the plot of the fluorescence intensity (protein solution with probe minus the same protein solution with water) vs. protein mass fraction was calculated using linear regression analysis and used as an index of the surface hydrophobicity. All intensity data were arbitrarily divided by 10000 prior to statistical analysis and graphing.

\section{Functional properties}

\section{Emulsifying properties}

The emulsifying activity (EA) and emulsion stability (ES) were determined according to Yasumatsu et al. (25). In brief, $1 \mathrm{~g}$ of fermented PPF was suspended in $14.3 \mathrm{~mL}$ of Milli-Q water (Millipore Corp.) and adjusted to $\mathrm{pH}=4.0$ or 7.0 with either $0.5 \mathrm{M} \mathrm{NaOH}$ or $\mathrm{HCl}$. The solution was stirred for $30 \mathrm{~min}$ using a mechanical stirrer (500 rpm) (RO 5; IKA Works Inc.) at room temperature $\left(21-23^{\circ} \mathrm{C}\right)$. Then, $14.3 \mathrm{~mL}$ of canola oil were added, followed by homogenization using an Omni macro-homogenizer (Omni International, Marietta, GA, USA), equipped with a 20-mm saw tooth probe, at speed 4 (approx. $7200 \mathrm{rpm}$ ) for $1 \mathrm{~min}$. A $10-\mathrm{mL}$ aliquot of the emulsion was poured into two $15-\mathrm{mL}$ centrifuge tubes and centrifuged at $1300 \times \mathrm{g}$ for 5 min (model 5810R; Eppendorf, Mississauga, ON, Canada). The emulsifying activity was determined as follows:

$$
\mathrm{EA}=\frac{h_{0}}{h_{1}} \cdot 100
$$

where $h_{0}$ is the total height of the emulsion layer prior to centrifugation and $h_{1}$ is the total height of the emulsion layer after centrifugation. Emulsion stability was determined by preparing the emulsion as previously described, then heating it at $80^{\circ} \mathrm{C}$ for $30 \mathrm{~min}$ using a water bath. The emulsion was then cooled to room temperature using tap water over a 30-minute period. A $10-\mathrm{mL}$ aliquot of the cooled to room temperature emulsion was then placed into two $15-\mathrm{mL}$ centrifuge tubes and centrifuged at $1300 \times \mathrm{g}$ for $5 \mathrm{~min}$. Emulsion stability was determined as follows:

$$
E S=\frac{E A_{H}}{E A} \cdot 100
$$

where $E A_{H}$ is the emulsifying activity of the heated emulsion and $E A$ of the unheated emulsion.

\section{Foaming properties}

The foam capacity (FC) and foam stability (FS) were determined according to Liu et al. (26). In brief, $1 \mathrm{~g}$ of fermented PPF was dispersed within $25 \mathrm{~mL}$ of Milli-Q water (Millipore Corp.) and adjusted to $\mathrm{pH}=4.0$ or 7.0 with either $0.5 \mathrm{M} \mathrm{NaOH}$ or $\mathrm{HCl}$, and stirred for $30 \mathrm{~min}$ on a mechanical stirrer (500 rpm; RO 5; IKA Works Inc.) at room temperature $\left(21-23^{\circ} \mathrm{C}\right)$. A $15-\mathrm{mL}$ aliquot was then transferred into a $400-\mathrm{mL}$ beaker for foaming using an Omni Macro Homogenizer (Omni International), 
equipped with a 20-mm saw tooth probe, at speed 4 (aprox. $7200 \mathrm{rpm}$ ) for $5 \mathrm{~min}$. The resulting foamed sample was transferred to a $100-\mathrm{mL}$ graduated cylinder and the foam volume measured at time 0 and after $30 \mathrm{~min}$. FC and FS were determined as follows:

and

$$
\mathrm{FC}=\frac{V_{\mathrm{F} 0}}{V_{\text {sample }}} \cdot 100
$$

$$
\mathrm{FS}=\frac{V_{\mathrm{F} 30}}{V_{\mathrm{F} 0}} \cdot 100
$$

where $V_{F 0}$ is the volume of the foam at $0 \mathrm{~min}, V_{\text {sample }}$ is the initial volume of sample used $(15 \mathrm{~mL})$, and $V_{\mathrm{F} 30}$ is the foam volume after $30 \mathrm{~min}$.

\section{Nitrogen solubility index}

Fermented PPF samples (1 g) were suspended in $25 \mathrm{~mL}$ of Milli-Q water (Millipore Corp.) and adjusted to $\mathrm{pH}=4.0$ or 7.0 with either $0.5 \mathrm{M} \mathrm{NaOH}$ or $\mathrm{HCl}$ at room temperature $\left(21-23^{\circ} \mathrm{C}\right)$ and stirred on a mechanical stirrer (RO 5; IKA Works Inc.) at 500 rpm for $30 \mathrm{~min}$. The suspension was centrifuged at $3070 \times \mathrm{g}$ for $10 \mathrm{~min}$ (model 5804R; Eppendorf). The nitrogen solubility index (in \%) was determined by dividing the nitrogen measured in the supernatant by the original amount in the fermented samples, multiplied by 100 . Nitrogen mass fraction within the fermented PPF and the supernatant after extraction were determined using AOAC method 920.87 (19).

\section{Water hydration capacity and oil-holding capacity}

Water hydration capacity (WHC) and oil-holding capacity $(\mathrm{OHC})$ values for fermented PPF samples were determined according to Stone et al. (27) with slight modifications. In brief, 10 $\mathrm{mL}$ of canola oil (or water, $\mathrm{pH}=4.0$ or 7.0 for $\mathrm{WHC}$ ) were added to $1 \mathrm{~g}$ of PPF in a $50-\mathrm{mL}$ centrifuge tube. The mixture was vortexed for $10 \mathrm{~s}$ every $5 \mathrm{~min}$ for $30 \mathrm{~min}$, followed by centrifugation at 11 180xg for 15 min (model 5804R; Eppendorf). OHC or WHC values were determined as the mass change in fermented protein samples after decanting (wet protein PPF mass minus dry PPF mass) relative to the dry PPF mass $(1 \mathrm{~g})$.

\section{Statistical analysis}

All data is reported as the mean value \pm standard deviation of PPF derived from triplicate fermentation batches $(N=3)$. A one-way ANOVA with a Tukey's test was used to detect statistical differences in response to fermentation time within compositional, degree of hydrolysis and $\mathrm{OHC}$ data. A two-way ANOVA was used to test for significant differences between the main effects of fermentation time and $\mathrm{pH}$, along with their interaction for all surface and functional (except for $\mathrm{OHC}$ ) properties tested. All statistical analyses were performed with Systat v. 10 software (28).

\section{RESULTS AND DISCUSSION}

\section{Physicochemical properties}

Table 1 shows changes to the proximate composition and $\mathrm{pH}$ of the freeze-dried PPF as a function of fermentation time. All crude protein, ash, and lipid mass fractions changed significantly during fermentation $(p<0.05)$, presumably due to an increase in the bacterial biomass present and loss of carbohydrates during the process. In the case of the latter, carbohydrates decreased from approx. 53 to $37 \%$ (based on calculated difference) during fermentation. Crude fat content increased from 2.5 to $3.5 \%$ after $11 \mathrm{~h}$ of fermentation, most likely due to the loss of carbohydrates. Literature reports various effects of fermentation on the crude fat content of pulses. For instance, solid-state fermentation of chickpea tempeh flour decreased the fat content from $6.1 \%$ in the raw chickpea flour to $2.6 \%$ in the tempeh flour (29), whereas cowpea fat content slightly increased after fermentation, from 0.9 to approx. $2 \%$ (30). In the current study, protein mass fraction increased sharply from 42.9 to approx. $47 \%$ between 1 and $5 \mathrm{~h}$ of fermentation before leveling off, a result hypothesized to be associated with the exponential growth of the L. plantarum cells and the loss of carbohydrates. In contrast, the ash mass fraction increased steadily from 4.2 to $11.0 \%$ over the 11 -hour fermentation time, again thought to be due to the loss of carbohydrates.

Like other Lactobacillus spp., growth of L. plantarum during fermentation leads to the production of weak acids and the release of small peptides from the proteins, resulting in a reduction in $\mathrm{pH}$ from $\mathrm{pH}=7.5$ at time 0 to $\mathrm{pH}=4.3$ after $11 \mathrm{~h}$ of fermentation. Chandra-Hioe et al. (31) have previously reported a reduction in $\mathrm{pH}$ during fermentation of fermented chickpea and faba bean flour. Because of the $\mathrm{pH}$ reduction, the $\mathrm{pH}$ of the starting material and the fermented PPF (taken at different fermentation times) was readjusted to $\mathrm{pH}=4$ (near the protein $\mathrm{pl}$ ) and $\mathrm{pH}=7$ (representative of the neutralization process commonly used in commercial wet processing of protein ingredients) prior to measuring their surface and functional characteristics. Increase in protein mass fraction during fermentation appears to be system-dependent. Chandra-Hioe et al. (31) reported no change in the protein content of desi or kabuli chickpea flour after $16 \mathrm{~h}$ of fermentation; however, the protein content of faba bean flour rose from 23 to $30 \%$ over the same fermentation period. Reyes-Moreno et al. (29) and Akubor and Chukwu (32) reported a 22 and $18 \%$ increase in protein mass fraction of fermented chickpea flour and full fat African oil bean seed flour, respectively.

Changes to the degree of hydrolysis (DH) of PPF during fermentation showed a sigmoidal increase with a maximum value of approx. $13 \%$ after $11 \mathrm{~h}$ (Table 1). A one-way analysis of variance found that changes to the degree of hydrolysis with fermentation time were significant $(p<0.05)$, where values increased from $0 \%$ at time 0 to $9.7 \%$ after 5 h, $10.6 \%$ after $9 \mathrm{~h}$, and a further increase to $13.5 \%$ after $11 \mathrm{~h}$. During a preliminary study (data not shown), fermentation up to $48 \mathrm{~h}$ did not yield any further changes to the $\mathrm{DH}$ values, possibly because: 
Table 1. Changes to the composition (on dry mass basis), degree of hydrolysis and pH of pea protein-enriched flour fermented by Lactobacillus plantarum over an 11-hour time course

\begin{tabular}{ccccccc}
$t / \mathrm{h}$ & $w($ crude protein)/\% & $w($ crude ash)/\% & $w$ (crude lipid)/\% & $w($ crude CHO)/\% & $\mathrm{DH} / \%$ & $\mathrm{pH}$ \\
0 & $(40.1 \pm 1.2)^{\mathrm{a}}$ & $(4.2 \pm 1.2)^{\mathrm{a}}$ & $(2.5 \pm 0.1)^{\mathrm{a}}$ & 53.2 & - & $(7.5 \pm 0.0)^{\mathrm{a}}$ \\
1 & $(42.9 \pm 1.3)^{\mathrm{a}}$ & $(5.9 \pm 0.9)^{\mathrm{ab}}$ & $(2.9 \pm 0.4)^{\mathrm{ab}}$ & 48.3 & $(6.1 \pm 0.2)^{\mathrm{a}}$ & $(7.2 \pm 0.0)^{\mathrm{b}}$ \\
5 & $(46.6 \pm 0.7)^{\mathrm{b}}$ & $(5.9 \pm 0.7)^{\mathrm{ab}}$ & $(2.6 \pm 0.0)^{\mathrm{a}}$ & 44.9 & $(9.7 \pm 0.5)^{\mathrm{b}}$ & $(6.3 \pm 0.0)^{\mathrm{c}}$ \\
9 & $(46.4 \pm 0.1)^{\mathrm{b}}$ & $(8.4 \pm 1.4)^{\mathrm{bc}}$ & $(3.4 \pm 0.0)^{\mathrm{b}}$ & 41.8 & $(10.6 \pm 0.8)^{\mathrm{c}}$ & $(4.4 \pm 0.1)^{\mathrm{d}}$ \\
11 & $(48.1 \pm 0.4)^{\mathrm{b}}$ & $(11.0 \pm 0.4)^{\mathrm{c}}$ & $(3.5 \pm 0.0)^{\mathrm{b}}$ & 37.4 & $(13.5 \pm 0.0)^{\mathrm{d}}$ & $(4.3 \pm 0.0)^{\mathrm{e}}$ \\
\hline
\end{tabular}

$\mathrm{DH}=$ degree of hydrolysis, $\mathrm{CHO}=$ carbohydrates determined based on the percentage difference between $100 \%$ and the mean values of protein, ash, and lipid mass fractions. Data represent the mean value \pm standard deviation $(N=3)$. Data with different superscript letters in the same column are significantly different $(p<0.05)$

(i) the low $\mathrm{pH}$ of the medium (approx. 4.3) restricted further cleavage of the proteins, and (ii) no additional proteinase production occurred during the stationary phase of growth (22).

\section{Surface properties}

The surface charge (zeta potential) and hydrophobicity of all PPF samples at both $\mathrm{pH}=4$ and 7 are given in Figs. $1 \mathrm{a}$ and $1 \mathrm{~b}$, respectively. Overall, the zeta potential (ZP) of the PPF was positive when adjusted to $\mathrm{pH}=4$ and negative when at $\mathrm{pH}=7$, as the proteins would be below and above, respectively, the isoelectric point of pea protein (pl 4.6) (Fig. 1a). As determined by a two-way ANOVA for ZP data, both the effects of fermentation time and $\mathrm{pH}$, and their interaction, were significant $(\mathrm{p}<0.001)$. At $\mathrm{pH}=4$ the $\mathrm{ZP}$ increased from approx. $+14 \mathrm{mV}$ in the unfermented sample to a maximum of $+27 \mathrm{mV}$ in 1-hour fermented samples, followed by a gradual decline to $+10 \mathrm{mV}$ by 11-hour fermentation. In contrast, at $\mathrm{pH}=7$ the $\mathrm{ZP}$ increased gradually from $-37 \mathrm{mV}$ at time 0 to $-27 \mathrm{mV}$ at $11 \mathrm{~h}$ of fermentation (Fig. 1a). The decreases in charge density at both $\mathrm{pH}$ values may indicate that limited hydrolysis of PPF leads to exposure of few numbers of both positively- and negatively-charged groups since changes in net charge at both $\mathrm{pH}$ values were low. A decrease in $\mathrm{ZP}$ at $\mathrm{pH}=7$ due to an increase in degree of hydrolysis was reported by Ghribi et al. (33) where chickpea protein isolate was modified via enzymatic hydrolysis.

A two-way ANOVA for surface hydrophobicity data found that both the fermentation time and $\mathrm{pH}$, and their interaction, were all significant $(p<0.001)$. In samples at $\mathrm{pH}=4$ surface hydrophobicity remained constant (approx. 9 arbitrary units, $\mathrm{AU}$ ) between 0 and $1 \mathrm{~h}$ of fermentation, and then steadily increased to approx. $21 \mathrm{AU}$ in 9-hour samples, at which time it plateaued (Fig. 1b). In contrast, at $\mathrm{pH}=7$ surface hydrophobicity declined very slightly from approx. $8 \mathrm{AU}$ in the unfermented samples to approx. $7 \mathrm{AU}$ in 11-hour fermented samples (Fig. $1 \mathrm{~b}$ ). It is hypothesized that at $\mathrm{pH}=4.0$, after $1 \mathrm{~h}$ of fermentation hydrolysis of the PPF leads to a partial unraveling of the protein and release of peptides which exposed buried reactive charged and hydrophobic sites (34). However, after 1 h, fermentation-induced changes to the surface properties reflect the continued unraveling of the protein structure and the increase in bacterial biomass protein. Since the protein would be only weakly charged at this $\mathrm{pH}$, conformational entropy would be greater allowing it to unravel more, as evidenced by an increase in hydrophobicity and a slight decline in charge. In contrast, for samples at $\mathrm{pH}=7$, sufficient electrostatic repulsion between particles would overshadow the minor changes that would occur in protein conformation (and hence surface charge and hydrophobicity) as the result of fermentation.
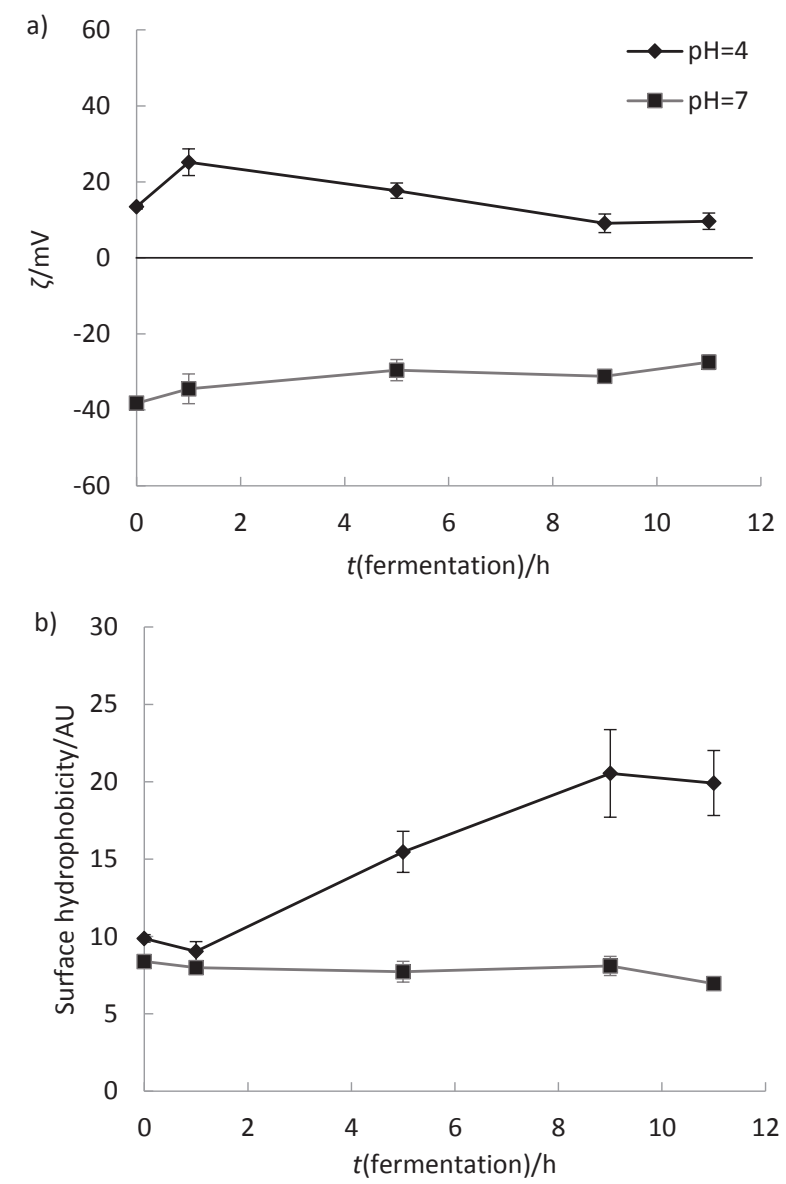

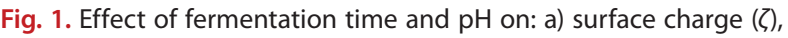
and b) hydrophobicity of pea protein-enriched flour fermented by Lactobacillus plantarum. Data represent the mean value \pm standard deviation $(N=3)$

\section{Functional properties}

Emulsification

The emulsifying activity (EA) and emulsion stability (ES) of fermented PPF as a function of fermentation time and $\mathrm{pH}$ are given in Figs. $2 a$ and $2 b$. A two-way ANOVA found that 
fermentation time, $\mathrm{pH}$ and their associated interaction have a highly significant effect on both EA and ES ( $p<0.001)$. The EA, a measure of emulsion forming ability, was constant (approx. $45 \%$ ) between 0 and $5 \mathrm{~h}$ of fermentation, and then declined significantly to approx. 5-7 \% after $9 \mathrm{~h}$ of fermentation (Fig. 2a) at $\mathrm{pH}=4$. This decline corresponds to the sharp increase in hydrophobicity observed at the corresponding $\mathrm{pH}$ in 5-hour fermented samples. The increased hydrophobicity may have impacted the protein's ability to migrate to the oil-water interface to lower interfacial tension and facilitate emulsion formation and possibly favour the aggregation of released peptides and unhydrolyzed proteins (35). Emulsion formation was lower (EA approx. $35 \%)$ at $\mathrm{pH}=7$ compared to $\mathrm{pH}=4$ between fermentation time 0 and $5 \mathrm{~h}$, however, EA remained relatively constant over the $11 \mathrm{~h}$ of fermentation at $\mathrm{pH}=7$, possibly due to the higher charge density and conformational flexibility of peptide and protein molecules (35). However, the emulsions formed at $\mathrm{pH}=4$ were inherently less stable than those formed at $\mathrm{pH}=7$, except after $11 \mathrm{~h}$ of fermentation where the ES was similar at each $\mathrm{pH}$. At $\mathrm{pH}=4$, ES values were relatively constant at approx. $20 \%$ over the entire fermentation time course; whereas, at $\mathrm{pH}=7, \mathrm{ES}$ values increased from approx. $37 \%$ at time 0 to approx. $56 \%$ at $5 \mathrm{~h}$, and then declined to approx. $20 \%$ by the end of fermentation (Fig. 2b). Unfortunately, a clear mechanism underlining emulsion stability could not be reached in this study, due to several confounding effects associated with changes in surface characteristics and solubility during the fermentation time $/ \mathrm{pH}$, as well as other factors, not measured as part of this study such as differences in droplet sizes and rate of creaming based on Stokes's law, and the concentration and viscoelasticity of the film formed at the oil-water interface.

\section{Foaming}

The foam capacity (FC) and stability of PPF and fermented PPF as a function of fermentation time and $\mathrm{pH}$ is given in Figs. $2 \mathrm{c}$ and $2 \mathrm{~d}$. Fermentation time, $\mathrm{pH}$ and their associated interaction all had a very significant effect on FC $(p<0.001)$. In contrast, for FS data only the effect of fermentation time and the interaction of fermentation time with $\mathrm{pH}$ were significant $(p<0.001)$. The foam-forming properties of PPF at $\mathrm{pH}=4$ increased FC from approx. $80 \%$ at time 0 to approx. $90 \%$ FC after $5 \mathrm{~h}$ of fermentation, and thereafter declined to approx. $70 \%$ after 9 h of fermentation (Fig. 2c). Similar to emulsions, the foam forming properties of a protein depend on its ability to migrate to the air-water interface to lower surface tension, and then realign its hydrophobic groups towards the apolar phase and the hydrophilic groups towards the polar phase. At $\mathrm{pH}=4$, an increase in FC was observed as the protein unravels and exposes hydrophobic groups; however, after $5 \mathrm{~h}$ of fermentation, it was presumed that an overabundance of hydrophobic groups were exposed, reducing the ability of the protein to migrate to the interface and therefore decreasing FC. At $\mathrm{pH}=7$, some variability was evident within the fermentation period, but $\mathrm{FC}$ values remained relatively constant at approx. $70 \%$ (Fig. 2c), which was most likely due to the relatively constant surface properties at this $\mathrm{pH}$ (Fig. 1). Foam stability at $\mathrm{pH}=4$ was relatively constant at approx. $20 \%$ for samples up to $5 \mathrm{~h}$ of fermentation, but then dropped to $9 \%$ after $9 \mathrm{~h}$ of fermentation. It was hypothesized that longer fermentation times lead to greater hydrophobicity, which may have inhibited the migration of protein to the air-water interface where bubbles continually broke and reformed. In contrast, at $\mathrm{pH}=7$, FS of samples remained relatively constant at approx. $20 \%$ over the entire fermentation period (Fig. 2d). No large changes in the surface properties of the PPF were evident at $\mathrm{pH}=7$, leading to the observed constant FS. The foaming properties of African oil bean seed (Pentaclethra macrophylla) flour (32), African breadfruit seed (Treculia africana) flour (36), and peanut protein concentrate (37) all improved after fermentation.

\section{Nitrogen solubility indices}

The nitrogen solubility indices (NSI) of PPF as a function of fermentation time and $\mathrm{pH}$ are shown in Fig. 2e. The effect of fermentation time, $\mathrm{pH}$ and their associated interaction, all had a significant effect on NSI $(p<0.001)$. Overall, NSI were relatively low at approx. $8-11 \%$ at $\mathrm{pH}=4$ regardless of the fermentation time; whereas, at $\mathrm{pH}=7, \mathrm{NSI}$ decreased from approx. 43 to $36 \%$ after 11 h of fermentation (Fig. 2e). Increased nitrogen solubility at the higher $\mathrm{pH}$ is associated with the greater surface charge and amount of electrostatic repulsive forces present relative to $\mathrm{pH}=4$, which is closer to the $\mathrm{pl}$ of PPF. The slight decline in $\mathrm{NSI}$ at $\mathrm{pH}=7$ is hypothesized to be attributed to the increase in biomass protein which was presumed to have lower solubility than the pea protein.

\section{Water hydration capacity}

The WHC of fermented PPF as a function of fermentation time and $\mathrm{pH}$ is given in Fig. 2f. A two-way ANOVA of WHC data found only the effect of fermentation time $(p<0.001)$ and its interaction with $\mathrm{pH}(\mathrm{p}<0.01)$ to be significant, but not the effect of $\mathrm{pH}$ alone ( $\mathrm{p}>0.05)$. WHC values declined from approx. 1-1.2 $\mathrm{g} / \mathrm{g}$ at time 0 to $0.8-0.9 \mathrm{~g} / \mathrm{g}$ after $5 \mathrm{~h}$ of fermentation, and then increased to $1.5-1.6 \mathrm{~g} / \mathrm{g}$ after $9 \mathrm{~h}$ of fermentation at both $\mathrm{pH}$ values, however, which one was greater $(\mathrm{pH}=4$ vs. 7) seemed to fluctuate a little within this trend (Fig. 2f). For instance, WHC at $\mathrm{pH}=4$ was slightly greater than $\mathrm{WHC}$ at $\mathrm{pH}=7$ at $t=0$ and $9 \mathrm{~h}$, whereas $\mathrm{WHC}$ at $\mathrm{pH}=7$ was slightly greater than $\mathrm{WHC}$ at $\mathrm{pH}=4$ for $t=1$ and $5 \mathrm{~h}$, with both $\mathrm{pH}$ values being similar in magnitude at $t=11 \mathrm{~h}$ (Fig. 2f). We hypothesized these findings were associated with protein hydrolysis to a point where the pea proteins unravel to expose buried hydrophilic sites which then interact with more water. Similarly, Xiao et al. (38) found that the fermentation of chickpea with Cordyceps militaris SN-18 significantly increased the WHC. In another study, Oloyede et al. (39) reported that the WHC of Moringa oleifera seed flour increased during the first $24 \mathrm{~h}$ of fermentation and then, after $72 \mathrm{~h}$, it declined. Similarly, Akubor and Chukwu (32) reported that the water absorption properties of African oil bean (Pentaclethra macrophylla) seed flour increased by $36 \%$ when fermented. 

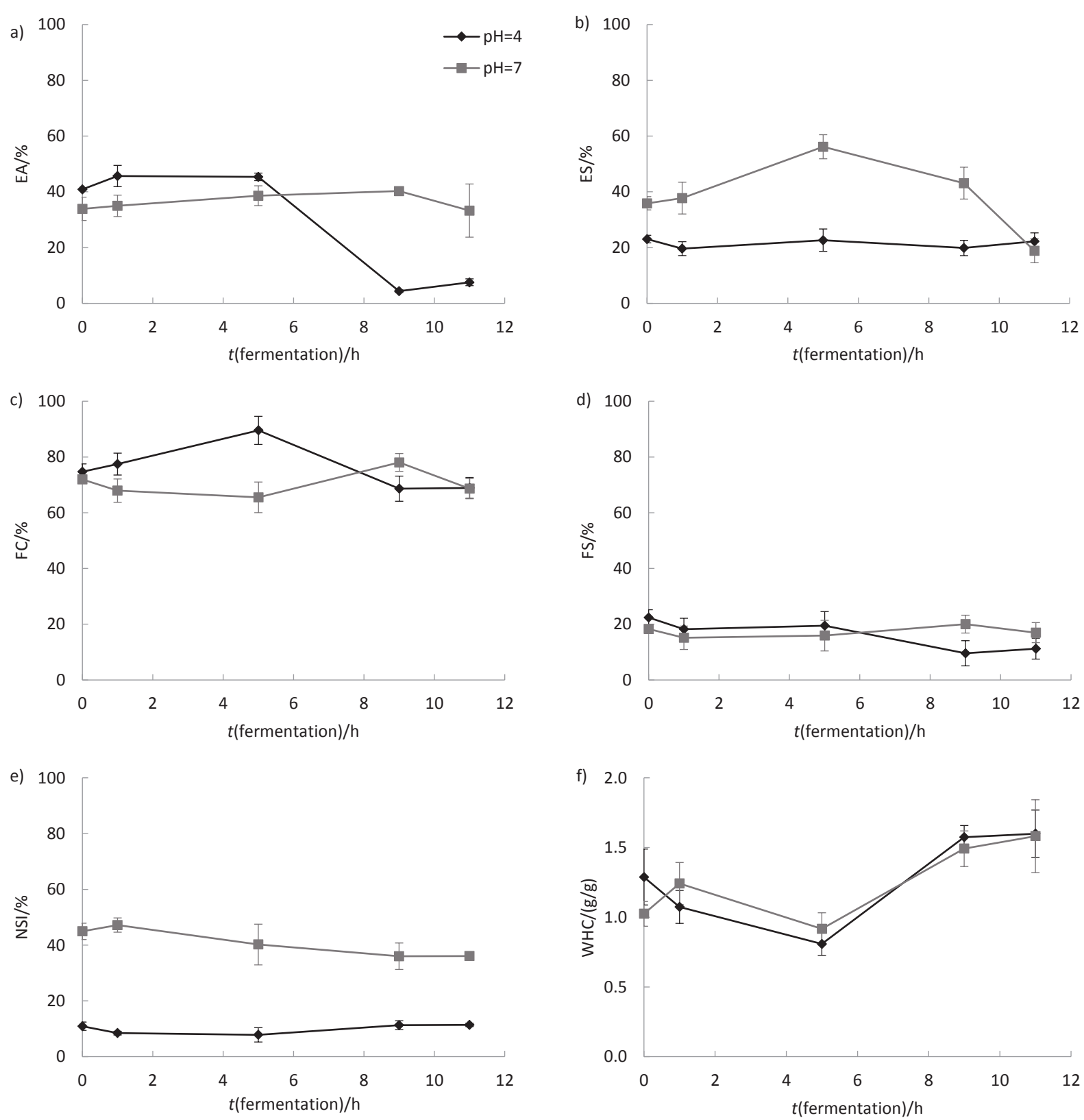

Fig. 2. Effect of fermentation time and pH on: a) emulsifying activity (EA), b) emulsion stability (ES), c) foam capacity (FC), d) foam stability (FS), e) nitrogen solubility index (NSI), and f) water hydration capacity (WHC) of pea protein-enriched flour fermented by Lactobacillus plantarum. Data represent the mean value \pm standard deviation $(\mathrm{N}=3)$

\section{Oil-holding capacity}

Fig. 3 shows the OHC of PPF as a function of fermentation time. Fermentation time had a significant effect on $\mathrm{OHC}$ $(p<0.001)$ as determined by a one-way ANOVA. Overall, OHC increased from approx. $1.8 \mathrm{~g} / \mathrm{g}$ at time $0 \mathrm{~h}$ to approx. $3.5 \mathrm{~g} / \mathrm{g}$ after $1 \mathrm{~h}$ of fermentation, after which it declined to $2.5 \mathrm{~g} / \mathrm{g}$ at $9 \mathrm{~h}$ of fermentation and then increased again to $3.5 \mathrm{~g} / \mathrm{g}$ after $11 \mathrm{~h}$ (Fig. 3). Since we did not adjust the $\mathrm{pH}$ during the $\mathrm{OHC}$ test, the $\mathrm{pH}$ would have differed depending on the fermentation time (Table 1). The $\mathrm{pH}$ declined from $\mathrm{pH}=7.5$ to 4.3 over the $11 \mathrm{~h}$ of fermentation, which resulted in a decrease in protein surface charge and solubility as well as an increase in hydrophobicity to allow for increased protein interactions with oil. As evident in Fig. 1b, surface hydrophobicity increased greatly at $\mathrm{pH}=4$ relative to $\mathrm{pH}=7$. During fermentation, the proteins become partially unraveled to expose buried hydrophobic groups that can bind oil. Fermentation also increased bacterial biomass in the PPF, which in this case altered $\mathrm{OHC}$ in a positive manner. There are also reports on an increase in $\mathrm{OHC}$ in fermented chickpea and faba bean flours (31). Periago et al. (40) reported a similar increase in $\mathrm{OHC}$ with an increase in degree of hydrolysis (via enzymatic modification) of pea flour. 


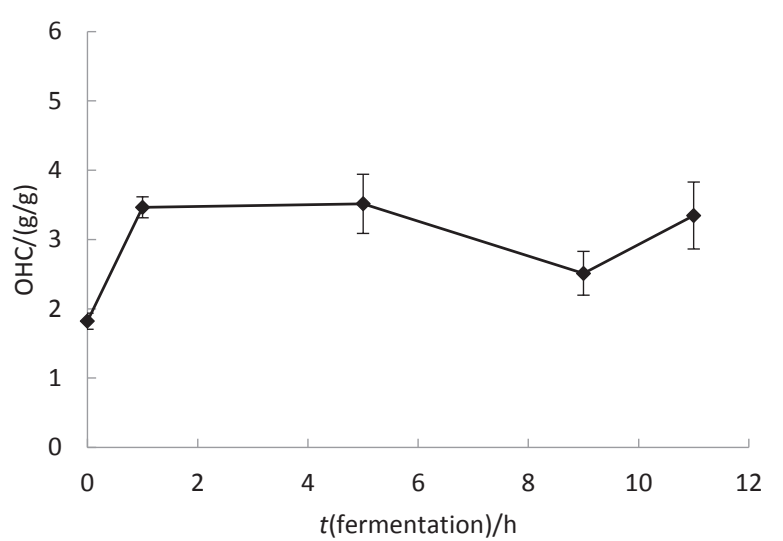

Fig. 3. Effect of fermentation time on the oil-holding capacity $(\mathrm{OHC})$ of pea protein-enriched flour fermented by Lactobacillus plantarum. Data represent the mean value \pm standard deviation $(N=3)$

\section{CONCLUSIONS}

Lactobacillus plantarum fermentation of pea protein-enriched flour over the course of $11 \mathrm{~h}$ achieved $13.5 \%$ degree of hydrolysis, a drop in $\mathrm{pH}$ and significant changes to the protein surface and functional properties. Crude protein and ash mass fractions of the PPF increased as fermentation time increased due to the microbial proliferation, as the amount of biomass increased and the amount of carbohydrates declined. During fermentation, enzymes cleave part of the protein causing the changes in conformation, exposing the buried hydrophobic sites and resulting in higher hydrophobicity of the PPF, at $\mathrm{pH}=4$, after longer fermentation times. Depending on the time, different levels of hydrolysis led to different surface characteristics and functionality of PPF. The final functionality of the fermented ingredients, like other proteins, can be further tailored depending on extrinsic factors, such as solution $\mathrm{pH}$. For instance, fermented PPF exhibited relatively better emulsion stability at $\mathrm{pH}=7$ after $5 \mathrm{~h}$ of fermentation and improved foam capacity at $\mathrm{pH}=4$ after $5 \mathrm{~h}$ of fermentation. It is important to note that the final ingredient is a blend of both pea protein and microbial biomass, giving its novel properties, which is highly dependent on both $\mathrm{pH}$ and length of fermentation. Overall, the fermented PPFs have the potential to be incorporated into food products, such as beverages, sports bars, nutritional supplements, and so on. The use of fermented pea protein may be advantageous or disadvantageous, depending on the level of hydrolysis and food environment, all of which could influence its functional attributes. Although not tested as part of this study, fermented ingredients also tend to have unique flavour profiles, reduced non-nutritive compounds and bioactive peptides for enhanced nutrition.

\section{ACKNOWLEDGEMENTS}

The Global Institute for Food Security at the University of Saskatchewan (Saskatoon, SK) and the Saskatchewan Ministry of Agriculture Development Fund (ADF\#: 2014-0283) provided financial support for this research.

\section{REFERENCES}

1. Tulbek MC, Lam RSH, Wang Y, Asavajaru P, Lam A. Pea: A sustainable vegetable protein crop. In: Nadathur SR, Wanasundara JPD, Scanlin L, editors. Sustainable protein sources. Cambridge, MA, USA: Academic Press; 2017. pp. 145-64. https://doi.org/10.1016/B978-0-12-802778-3.00009-3

2. Leterme P, Monmart T, Baudart E. Amino acid composition of pea (Pisum sativum) proteins and protein profile of pea flour. J Sci Food Agric. 1990;53(1):107-10. https://doi.org/10.1002/jsfa.2740530112

3. Reinkensmeier A, Bußler S, Schlüter O, Rohn S, Rawel HM. Characterization of individual proteins in pea protein isolates and air classified samples. Food Res Int. 2015;76(Pt. 1): 160-7.

https://doi.org/10.1016/j.foodres.2015.05.009

4. Multari S, Stewart D, Russell WR. Potential of fava bean as future protein supply to partially replace meat intake in the human diet. Compr Rev Food Sci Food Saf. 2015;14(5):511-22. https://doi.org/10.1111/1541-4337.12146

5. Patterson CA, Curran J, Der T. Effect processing on antinutrient compounds in pulses. Cereal Chem. 2017;94(1):2-10. https://doi.org/10.1094/CCHEM-05-16-0144-FI

6. Kiosseoglou V, Paraskevopoulou A. Functional and physicochemical properties of pulse proteins. In: Tiwari BK, Gowen $A$, McKenna B, editors. Pulse foods: Processing, quality and nutraceutical applications. Oxford, UK: Academic Press; 2011. pp. 57-90.

https://doi.org/10.1016/B978-0-12-382018-1.00003-4

7. Global protein ingredients market size, industry report, 2018-2025. San Francisco, CA, USA: Grand View Research; 2018. Report ID: 978-1-68038-451-2.

8. Hall C, Hillen C, Garden Robinson J. Composition, nutritional value, and health benefits of pulses. Cereal Chem. 2017; 94(1):11-31.

https://doi.org/10.1094/CCHEM-03-16-0069-FI

9. Sozer N, Holopainen-Mantila U, Poutanen K. Traditional and new food uses of pulses. Cereal Chem. 2017;94(1):66-73. https://doi.org/10.1094/CCHEM-04-16-0082-FI

10. Shiba K, Negishi Y, Okada K, Nagao S. Chemical changes during sponge-dough fermentation. Cereal Chem. 1990; 67(4):350-5.

11. Fernandez-Orozco R, Frias J, Muñoz R, Zielinski H, Piskula MK, Kozlowska H, Vidal-Valverde C. Fermentation as a bio-process to obtain functional soybean flours. J Agric Food Chem. 2007;55(22):8972-9.

https://doi.org/10.1021/jf071823b

12. Lee IH, Hung YH, Chou CC. Solid-state fermentation with fungi to enhance the antioxidative activity, total phenolic and anthocyanin contents of black bean. Int J Food Microbiol. 2008;121(2):150-6.

https://doi.org/10.1016/j.ijfoodmicro.2007.09.008 
13. Tavano OL. Protein hydrolysis using proteases: An important tool for food biotechnology. J Mol Catal B Enzym. 2013;90:1-11.

https://doi.org/10.1016/j.molcatb.2013.01.011

14. Hemalatha S, Platel, K, Srinivasan K. Influence of germination and fermentation on bioaccessibility of zinc and iron from food grains. Eur J Clin Nutr. 2006;61:342-8.

https://doi.org/10.1038/sj.ejcn.1602524

15. Martín-Cabrejas MA, Sanfiz B, Vidal A, Mollá E, Esteban R, López-Andréu FJ. Effect of fermentation and autoclaving on dietary fiber fractions and antinutritional factors of beans (Phaseolus vulgaris L.). J Agric Food Chem. 2004;52(2):2616.

https://doi.org/10.1021/jf034980t

16. Mohite BV, Chaudhari GA, Ingale HS, Mahajan VN. Effect of fermentation and processing on in vitro mineral estimation of selected fermented foods. Int Food Res J. 2013;20(3):1373-7.

17. de Vries MC, Vaughan EE, Kleerebezem M, de Vos WM. Lactobacillus plantarum-survival, functional and potential probiotic properties in the human intestinal tract. Int Dairy J. 2006:16(9);1018-28.

https://doi.org/10.1016/j.idairyj.2005.09.003.

18. AOAC Official Method 925.10. Solids (total) and moisture in flour. Gaithersburg, MD, USA: AOAC International; 2005.

19. AOAC Official Method 920.87. Protein (total) in flour. Gaithersburg, MD, USA: AOAC International; 2005.

20. AOAC Official Method 923.03. Ash of flour. Gaithersburg, MD, USA: AOAC International; 2005.

21. AOAC Official Method 920.39. Fat (crude) or ether extraction in animal feed. Gaithersburg, MD, USA: AOAC International; 2005.

22. Adler-Nissen J. Determination of the degree of hydrolysis of food protein hydrolysates by trinitrobenzenesulfonic acid. J Agric Food Chem. 1979;27(6):1256-62.

https://doi.org/10.1021/jf60226a042

23. Can Karaca A, Low N, Nickerson M. Emulsifying properties of chickpea, faba bean, lentil and pea proteins produced by isoelectric precipitation and salt extraction. Food Res Int. 2011;44(9):2742-50.

https://doi.org/10.1016/j.foodres.2011.06.012

24. Kato A, Nakai S. Hydrophobicity determined by a fluorescence probe method and its correlation with surface properties of proteins. Biochim Biophys Acta Protein Struct. 1980;624(1):13-20.

https://doi.org/10.1016/0005-2795(80)90220-2

25. Yasumatsu K, Sawada K, Moritaka S, Misaki M, Toda J, Wada T, Ishii K. Whipping and emulsifying properties of soybean products. Agric Biol Chem. 1972;36(5):719-27.

https://doi.org/10.1080/00021369.1972.10860321

26. Liu S, Elmer C, Low NH, Nickerson MT. Effect of pH on the functional behaviour of pea protein isolate-gum Arabic complexes. Food Res Int. 2010;43(2):489-95.

https://doi.org/10.1016/j.foodres.2009.07.022

27. Stone AK, Karalash A, Tyler RT, Warkentin TD, Nickerson MT. Functional attributes of pea protein isolates prepared using different extraction methods and cultivars. Food Res Int. 2015;76(Pt.1):31-8.

28. Systat v. 10 software, Systat Software Inc., San Jose, CA, USA; 2000.

29. Reyes-Moreno C, Cuevas-Rodríguez EO, Milán-Carrillo J, Cárdenas-Valenzuela OG, Barrón-Hoyos J. Solid state fermentation process for producing chickpea (Cicer arietinum L) tempeh flour. Physicochemical and nutritional characteristics of the product. J Sci Food Agric. 2004;84(3):271-8. https://doi.org/10.1002/jsfa.1637

30. Prinyawiwatkul W, Beuchat LR, McWatters KH, Phillips RD. Fermented cowpea flour: Production and characterization of selected physico-chemical properties. J Food Process Preserv. 1996;20(4):265-84.

https://doi.org/10.1111/j.1745-4549.1996.tb00747.x

31. Chandra-Hioe MV, Wong CHM, Arcot J. The potential use of fermented chickpea and faba bean flour as food ingredients. Plant Foods Hum Nutr. 2016;71(1):90-5. https://doi.org/10.1007/s11130-016-0532-y

32. Akubor PI, Chukwu JK. Proximate composition and selected functional properties of fermented and unfermented African oil bean (Pentaclethra macrophylla) seed flour. Plant Foods Hum Nutr. 1999;54:227-38.

https://doi.org/10.1023/A:1008100930856

33. Ghribi AM, Gafsi IM, Sila A, Blecker C, Danthine S, Attia H, et al. Effects of enzymatic hydrolysis on conformational and functional properties of chickpea protein isolate. Food Chem. 2015;187:322-30.

https://doi.org/10.1016/j.foodchem.2015.04.109

34. Zheng L, Zhao Y, Xiao C, Sun-Waterhouse D, Zhao M, Su G. Mechanism of the discrepancy in the enzymatic hydrolysis efficiency between defatted peanut flour and peanut protein isolate by Flavorzyme. Food Chem. 2015;168:100-6. https://doi.org/10.1016/j.foodchem.2014.07.037

35. Liang HN, Tang CH. pH-dependent emulsifying properties of pea [Pisum sativum (L.)] proteins. Food Hydrocoll. 2013; 33(2):309-19.

https://doi.org/10.1016/j.foodhyd.2013.04.005

36. Fasasi OS, Eleyinmi, AF, Oyarekua MA. Effect of some traditional processing operations on the functional properties of African breadfruit seed (Treculia africana) flour. LWT - Food Sci Technol. 2007;40(3):513-9. https://doi.org/10.1016/j.lwt.2005.11.009

37. Yu J, Ahmedna M, Goktepe I. Peanut protein concentrate: Production and functional properties as affected by processing. Food Chem. 2007;103(1):121-9. https://doi.org/10.1016/j.foodchem.2006.08.012 
38. Xiao Y, Xing G, Rui X, Li W, Chen X, Jiang M, Dong M. Effect of solid-state fermentation with Cordyceps militaris SN-18 on physicochemical and functional properties of chickpea (Cicer arietinum L.) flour. LWT - Food Sci Technol. 2015;63(2):1317-24.

https://doi.org/10.1016/j.lwt.2015.04.046

39. Oloyede OO, James S, Ocheme OB, Chinma CE, Akpa VE. Effects of fermentation time on the functional and pasting properties of defatted Moringa oleifera seed flour. Food Sci Nutr. 2016;4(1):89-95.

https://doi.org/10.1002/fsn3.262

40. Periago MJ, Vidal ML, Ros G, Rincón F, Martínez C, López $G$, et al. Influence of enzymatic treatment on the nutritional and functional properties of pea flour. Food Chem. 1998;63(1):71-8.

https://doi.org/10.1016/S0308-8146(97)00199-4 